\title{
The Effect of CEO Characteristics on Firm Performance of Food and Beverage Companies in Indonesia, Malaysia and Singapore
}

\section{Gatot Nazir AHMAD', Muhammad Ris Pripamuji PRASETYO², Agung Dharmawan BUCHDADI $^{3}$, SUHERMAN ${ }^{4 *}$, Umi WIDYASTUTI ${ }^{5}$, Herni KURNIAWATI ${ }^{6}$}

\author{
${ }^{1}$ Study Program of Master of Management, Faculty of Economics, State University of Jakarta, Indonesia \\ ${ }^{2}$ Study Program of Management, Faculty of Economics, State University of Jakarta, Indonesia \\ ${ }^{3}$ Study Program of Doctor in Management, Graduate School, State University of Jakarta, Indonesia \\ ${ }^{4}$ Study Program of Management, Faculty of Economics, State University of Jakarta, Indonesia, \\ Email: ahmad72nazir@gmail.com \\ ${ }^{5}$ Study Program of Digital Business, Faculty of Economics, State University of Jakarta, Indonesia \\ ${ }^{6}$ Department of Accounting, Faculty of Economics, Tarumanagara University, Jakarta, Indonesia \\ * Corresponding Author
}

\author{
Received: 18.11.2021 Accepted: 01.12.2021 Published: 02.02.2022 $\quad$ DOI: 10.47750/QAS/23.186.15
}

\begin{abstract}
This study aims to investigate the effect of CEO characteristics [used five surrogate indicators: 1) CEO gender, 2) CEO tenure, 3) CEO age 4) CEO education and 5) CEO nationality] on firm performance [applied four measures: 1) Return On Asset (ROA), 2) Return On Equity (ROE), 3) Return On Sales (ROS) and 4) Tobin's Q] in the context of food and beverage firms in Indonesia, Malaysia and Singapore. The sample was screened from 50 food and beverage firms consisting of 16 Indonesian firms, 19 Malaysian firms and 15 Singapore firms. The period of observation ranged from 2013 to 2018. This study uses panel data regression analysis, including the fixed effect model (FEM) with clustered standard errors. The empirical results showed that CEO gender has a significant effect on firm performance measured with Tobin's Q. Meanwhile, CEO gender does not have a significant effect to firm performance measured with ROA, ROE, and ROS. Furthermore, CEO nationality has a significant effect on firm performance measured with $R O A$ and Tobin's $Q$ but not significant measured with ROE and ROS. However, CEO tenure, CEO age and CEO education does not have significant effect on firm performance from the 5 indicator. At the end, from the robustness tests confirmed that CEO education is not significantly affect firm performance (all measures), and CEO nationality is significantly affect Tobin's $Q$ in Indonesia, Malaysia, and Singapore in the main regressions.
\end{abstract}

Keywords CEO gender; CEO tenure; CEO age; CEO education; CEO nationality; Firm performance, Panel Data Regression.

\section{Introduction}

The existence of a leader in a firm is essential for the firm's sustainability process. A firm leader called the Chief Executive Officer (CEO) has a great responsibility in improving the firm's performance, both in the short and long term. The decisionmaking power of the board of directors, especially the CEO, affects the firm's performance because CEO have absolute power in the firm's operational decision-making and substantial influence in strategic decision-making (Wu et al., 2011). Every firm should have professional directors or top management who are experts in their respective fields so that the firm can be appropriately managed and have a good image in the eyes of investors. Also, the leaders of these companies certainly have different characteristics or backgrounds, both in terms of education, experience, ethnicity, age, and others. Different or varied characteristics that the CEO has will affect the firm's performance both positively and negatively.
According to Hambrick \& Mason (1984), several characteristic dimensions are the main determinants of the behavior of a CEO, namely educational background, age, and work experience. In addition, Johnson et al. (2013) argue that individual characteristics of directors such as gender, experience, skills, age, and tenure can influence corporate decision-making. The dimensions of CEO characteristics tested in this study used gender, age, tenure, education, and nationality.

In leading a firm, a male or female CEO has the responsibility to make decisions and take actions, which will affect the firm's performance. Female CEOs are usually more conservative and very risk-averse. Companies with female CEOs tend to be more optimal in managing assets. Jannah (2015) and Khan \& Vieito (2013) found positive and significant results between CEO gender and firm performance. However, in contrast to the findings before, study from Peni \& Vähämaa (2010) and Jadiyappa et al. (2019), who found that CEO gender had a 
significant adverse effect on firm performance. Other results from research by Baloyi \& Ngwakwe (2017), Fujianti (2018), Rahman et al. (2017) found that CEO gender did not affect firm performance.

CEOs with long tenure at a firm are considered more capable of improving firm performance (Suherman et al., 2021). CEOs who have long tenure can convince investors that the firm has the opportunity to achieve higher firm performance (Sudana \& Aristina, 2017; Hidayati, 2017; Emestine \& Setyaningrum, 2019). However, in contrast to the research findings conducted by Al-Matari et al. (2012) and Liu \& Jiang (2020), who found that CEO tenure has a significant negative impact on firm performance.

Earlier CEOs have more comprehensive work experience both from within and from outside the firm (Saidu, 2019; Peni, 2014). Emestine \& Setyaningrum (2019) found that CEO age has a positive and significant effect on firm performance. However, it is different from the research results conducted by Setiawan \& Gestanti (2019) and Diks (2016), who found that CEO age had a significant adverse effect on firm performance. Another thing also found in research conducted by Liu \& Jiang (2020) found that CEO age did not affect firm performance.

Gottesman \& Morey (2006) explains that CEOs with a higher level of educational attainment will have management styles and characteristics that can help the firm, which will improve firm performance. Saidu (2019) and Setiawan \& Gestanti (2018) found a positive and significant effect between the CEO's education level and firm performance. On the other hand, Ying and Mei (2014) stated a negative and significant effect between CEO education level and firm performance. However, Ayaba (2012) and Gottesman \& Morey (2006) found no significant effect between CEO education level and firm performance.

Generally, the presence of foreign directors will have a good impact on the composition of the board. The background and experience possessed by foreign CEOs can be different success factors for the firm. Badru \& Raji (2016) argue that CEO nationality provides better placement of executive and shareholder interests, which improve firm competitiveness. Badru \& Raji (2016), Ujunwa (2012), Rahman et al. (2017) found that CEO nationality has a positive and significant effect on firm performance. However, this is different from the research results conducted by Kaur \& Singh (2018), which found that CEO nationality has a significant negative impact on firm performance.

Based on the explanation above, the effect of the CEO characteristics and firm performance show different results. Then, it raises the question of how the effect of the CEO's characteristics on the firm performance?. Therefore, this paper try to investigate the impact of the CEO characteristics on firm performance in Indonesia, Malaysia, and Singapore especially in food and baverages companies. Researcher choose food and baverages companies because this sector has become a profitable business. Businesses that engaged in this field are starting to proliferate; it showed from the number of companies that appear more and more. It is also related to the increase in Gross Domestic Product (GDP) in each country. It is undeniable that the community needs industries that engaged in this sector to last a long time and have long prospects.

Furthermore, researchers choose locations such as Indonesia, Malaysia, and Singapore because these three countries experience growth of the food and beverage industry sector and continue to proliferate. This growth continues to increase significantly from year to year. On the growth of the food and beverage sector industry in Indonesia, the Ministry of Industry noted that the food and beverage industry's contribution to the Indonesia's GDP of the non-oil and gas industry reached $34.95 \%$ in the second quarter of 2017 , the results of this performance made the food and beverage sector as an one of the essential contributors to Indonesia's GDP.

Not only in Indonesia, the growth of Malaysia's food and beverage sector has also experienced a significant increase; a large export market indicates this. The Department of Statistics Malaysia (DSM) noted that total revenue for the wholesale \& retail trade, food \& beverage, and accommodation segments grew by $8.5 \%$ in 2017 . The drivers of this increase contributed by the food and beverage sub-sector, which reached $10.8 \%$.

Furthermore, Singapore is a country that prioritizes the trade sector and relies heavily on export and import activities. The food and beverage industry sector plays an essential role in the business economy in Singapore and is also the country with the third-highest per capita income in the world in 2018. Singapore is also known as the lion city, the country with the most significant imports reaching $90 \%$; this makes the production sector in Singapore is the most significant GDP contributor. The Department of Statistics Singapore noted a CAGR growth within five years of $2.8 \%$ in the food and beverages sector from 2013 $-2018$.

In addition, researchers are motivated to conduct this study because the selection or appointment of CEOs is essential to be assessed from several characteristic dimensions so that it is interesting to be discussed by researchers. Our study advances the works of literature by enriching the empirical findings in related topics. Also, to the best of the authors' knowledge, this is one of the first studies in Indonesia using four measures of firm performance and a cross-country study of both developing and developed countries.

The paper organized as follows; section 2 reviews the relevant theoretical concept and hypotheses development. Section 3 elaborates on the research methods, data, sample, variables definition, and regression models. Section 4 presents the results and discussion. Section 5 summarizes the overall findings of the study as well as the potential exploration of future research.

\section{Literature review and hypotheses development}

\subsection{Literature review}

From a theoretical point of view, agency theory is the basis used to understand the issues between corporate governance and firm performance. Problems regarding corporate governance arise because of the differences in interests between capital owners or shareholders (principal) and managers (agent) (Jensen \& Meckling, 1976). Based on this theory, the manager (agent) is responsible for optimizing the firm's profits; on the other hand, the owners of capital also must optimize their wealth. In this theory, there is an asymmetrical relationship (information imbalance) between the two. Therefore, companies need to implement good corporate governance with the aim of the firm being healthy. Good corporate governance involves good supervision, the openness of information, and better transparency (Krafft et al., 2014).

Upper echelon theory is a theory developed by Hambrick \& Mason (1984), who argues that organization reflects top-level management. This theory states that organizational outcomes are partly predicted by the characteristics of the managerial background of the top-level management team. This theory states that executive background determines organizational outcomes, both at the action and the level of performance (Hambrick \& Mason, 1984). This theory also states that age, experience, education, social background, and economic conditions are managerial reflections in making strategies and decisions. In other words, this theory explains that decisionmaking in the firm is essentially the result of the characteristics, 
psychology, and social and economic background of top management. This theory is critical to consider because it will provide an idea of what can be controlled by the actions of the CEO's motives. It is because the actions of a CEO can impact firm performance, either directly or indirectly (Kaur \& Singh, 2018).

\subsection{Hypotheses development}

Gender issues are still one of the attractive managerial attributes to be researched. The previous literature states that gender differences can have an impact on individual success in the workplace. In a study conducted by Jannah (2015) that gender has a significant influence on the financial performance of going public companies. It shows that information processing and decision-making are based on different approaches, namely that men and women differ in their use of information processing to solve problems and make decisions. Mahbubi (2016) found that CEO gender had a positive and significant effect on firm performance. It shows that female CEOs can have a positive influence on firm performance. Companies with female CEOs have an average firm performance ratio calculated by the profitability ratio return on assets (ROA), which is higher than the average return on assets (ROA) of companies with male CEOs and the industry average. Companies with female CEOs tend to be more optimal in managing assets. It then contributes to the tendency of higher ROA values in companies with female CEOs. Based on this description, it can be assumed that CEO gender positively influences firm performance. Thus, hypothesis one is developed as follows:

$\mathrm{H} 1$ : Female CEO positively affects firm performance.

A CEO has an essential role in the sustainability of the firm. Aryati (2019) says that different levels of CEO tenure will affect both the CEO's leadership development and the opportunity to control management. A CEO with a long tenure signal that the CEO's level of professionalism and expertise increases, thereby increasing his power in influencing decisions (Sudana \& Aristina, 2017). It shows that having a CEO with a long tenure in a firm is considered to improve firm performance. Chou \& Chan (2018) stated that a longer CEO tenure results in better firm performance than a shorter CEO tenure. A study conducted by Hidayati (2017) found a significant between CEO tenure and firm performance. According to Emestine \& Setyaningrum (2019), CEO tenure positively affects firm performance in line with these findings. It explains that the longer the CEO's tenure is given, the better the firm's performance will be because the CEO's understanding of the firm's business processes is getting better, so he can carry out more precise monitoring of targets and provide better recommendations for firm operations. Thus, hypothesis two is developed as follows:

$\mathrm{H}$ 2: CEO tenure positively affects firm performance.

The CEO's age can be a factor in the success of a CEO in leading the firm. The CEO's age also affects the knowledge and experience possessed. Emestine \& Setyaningrum (2019) stated that experience measured by age was a significant factor. Because the old CEO has a broader range of work experience, both inside and outside the firm, it convinces investors that the CEO can lead the firm better. The age difference is a factor in how a person acts in taking risks. Behavioral finance explains that young CEOs tend to be ambitious and risk-takers or like to take risks. Vice versa, CEOs with an older age tend to take risks (risk reserve). A study conducted by Setiawan \& Gestanti (2019) found a significant negative effect between CEO age and firm performance. It indicates that the older the CEO, the lower the firm's performance. According to Serfling (2014), the older the CEO, the lower the cognitive function, which makes the CEO wrong in the estimate's accuracy. Based on this description, it can be assumed that CEO age has a negative effect on firm performance. Thus, hypothesis three is developed as follows:
H3: CEO age positively affects firm performance.

The education level of the CEO affects the knowledge and insight possessed. Maulia \& Januarti (2014) said the higher the education taken, formal and non-formal education according to the field of work, the higher the intellectual experience possessed. Furthermore, this will make it easier for someone to carry out their work. In research conducted by Darmadi (2012) and Erlim \& Juliana (2017) found a positive influence between CEO education level and firm performance. This result is in line with Setiawan \& Gestanti (2018) findings, which found a positive effect between CEO education level and firm performance. Ayaba (2012) argued that companies controlled by CEOs with a higher education level (postgraduate) tend to record higher firm performance than CEOs with a bachelor's degree. Gottesman \& Morey (2006) explain that CEOs with higher levels of educational attainment will have management styles and characteristics that can help the firm, which will improve firm performance. Based on this description, it can be assumed that the CEO's education level positively affects firm performance. Thus, hypothesis four is developed as follows:

H4: CEO education positively affects firm performance.

One form of diversity expected in the era of globalization is the diversity of citizenship among board members. Generally, the presence of foreign directors will have a good impact on the composition of the board. The background and experience of foreign CEOs can be a different success factor for the firm. Badru \& Raji (2016) confirmed the positive effect between CEO nationality and firm performance, indicating that CEO nationality provides better placement of executive and shareholder interests, which increases the firm's competitiveness. According to Ujunwa (2012) council, citizenship is positive and very significant. It suggests that foreign board members offer greater financial flexibility, which provides an opportunity to reduce the cost of capital by reducing cross-border information gaps. Then, the presence of foreign board members in line with agency theory promotes monitoring quality, reduces managerial costs and agency costs. Thus, hypothesis five is developed as follows:

H5: CEO nationality positively affects firm performance

\section{Research methods}

\subsection{Data and sample}

This study investigates whether CEO characteristics affect firm performance. The sample in this study were food and beverage companies in Indonesia, Malaysia, and Singapore. We chose this sector because the food and beverage industry is a sector that has long prospects, which means that companies in this sector are not affected by macroeconomic movements or business conditions in general (Pertiwi \& Pratama, 2012). The initial sample of the study consisted of food and beverage companies listed on the Indonesia Stock Exchange (IDX), Bursa Malaysia (MYX), and Singapore Exchange (SGX) for the period from 2013 to 2018. Using secondary data, annual reports are used for research purposes in food companies and beverages listed on the IDX, MYX, and SGX in 2013 - 2018.

We used a purposive sampling method to maintain the same number of observations during the observed years. Therefore, we cut 60 companies consisting of 15 Indonesian companies, 20 Malaysian companies, and 25 Singaporean companies, resulting in 50 food and beverage companies consisting of 16 Indonesian companies, 19 Malaysian companies, and 15 Singaporean companies with consistent information (balanced) during the observation period covering 2013 - 2018. With the criteria used in determining the sample:

1. The sample must be actively registered on the IDX, MYX, and SGX from 2013 to 2018. 


\section{GENERAL MANAGEMENT}

2. The sample operates in a food and beverage firm.

3. The sample publishes an annual report by presenting the complete data.
A more detailed sample distribution is presented in Table

\begin{tabular}{|c|c|c|c|c|}
\hline \multirow{2}{*}{ No. } & \multirow{2}{*}{ Criteria } & \multicolumn{3}{|l|}{ Country } \\
\hline & & Indonesia & Malaysia & Singapore \\
\hline 1 & $\begin{array}{l}\text { Food and Beverages sector companies that issued consecutive } \\
\text { financial reports in the period } 2013-2018 \text {. }\end{array}$ & 14 & 19 & 25 \\
\hline 2 & $\begin{array}{l}\text { Food and beverage sector companies that do not provide and } \\
\text { displays data and information needed by researchers } \\
\text { regarding the variables in the study in full in financial and annual } \\
\text { reports }\end{array}$ & (1) & (1) & $(10)$ \\
\hline 3 & Total sample used & 16 & 19 & 15 \\
\hline 4 & $\begin{array}{l}\text { Total observation ( } 50 \text { Food and Beverages sector companies listed } \\
\text { on Indonesia Stock Exchange, Bursa Malaysia and Singapore } \\
\text { Exchange for the period } 2013-2018 \text { ). }\end{array}$ & 96 & 114 & 90 \\
\hline
\end{tabular}

Table 1: Sample selection criteria

\subsection{Variable measurement}

\subsubsection{Dependent variables}

The dependent variable is firm performance. In this study, we employed 4 (four) measures of firm performance (ROA, ROE, ROS, Tobin's $Q$ ) by referring to the studies of Buallay et al. (2017) and Kılıç \& Kuzey (2016). 1) ROA is the profitability ratio which shows the capacity and capability of management in using firm assets (Ujunwa, 2012); 2) ROE to measure financial performance; 3) ROS is a ratio used to evaluate a firm operational efficiency; 4) Tobin's $Q$ to measure performance market (Kılıç \& Kuzey, 2016).

\subsubsection{Independent variables}

The leading independent variables of this study are the CEO characteristics. Adopting the measures used by the study of Suherman et al. (2021), Jadiyappa et al. (2019), Khan \& Vieito (2013), Peni (2014), we created a dummy variable labeled as GDR, in which we mark 1 if the companies have female CEOs, and 0 otherwise. The second proxy of CEO characteristics is CEO tenure (TNR), constructed by following the measure developed by Al-Matari et al. (2012) and Suherman et al. (2021), where we count the number of years the CEO had held the position. The third proxy is CEO age (AGE), as measured by the age of the CEO (Setiawan \& Gestanti, 2019). The fourth proxy, CEO education (EDU), is the dummy variable, in which we mark 1 if the CEO has a master/doctoral degree and 0 otherwise (Ayaba, 2012). While, the last independent variable is CEO nationality (NAT) is the dummy variable, in which we mark 1 if the CEO is from foreign nations and 0 otherwise (Kaur \& Singh, 2018).

\subsubsection{Control variables}

We recognize that our proposed empirical model is not free from endogenous problems. To anticipate this, we include the control variables to avoid biased estimation. We meticulously selected our control variables by referring to prior studies (Buallay et al., 2017; Kaur \& Singh, 2018; Krafft et al., 2014; Ujunwa, 2012). These control variables are independence commissioner (BI), board size (BS), board diversity (BD), board of meeting (BM), leverage (LEV), sales growth (GROWTH), current ratio (CR), firm size (SIZE), cash flow (CF) and firm age (FA).

\begin{tabular}{|c|c|c|c|c|}
\hline No & Variable & Definition & Formula & Data form \\
\hline \multicolumn{5}{|c|}{ Dependent Variables } \\
\hline 1 & $\mathrm{ROA}$ & Return On Asset & Net Income/ total assets & Continuous \\
\hline 2 & ROE & Return On Equity & Net Income / total equity & Continuous \\
\hline 3 & ROS & Return On Sales & Net Income/ total sales revenue & Continuous \\
\hline 4 & Tobin's Q & Market performance & (Market values shares + Debt)/Total asset & Continuous \\
\hline \multicolumn{5}{|c|}{ Main independent variables of interest } \\
\hline 5 & GDR & CEO Gender & 1 if the CEO is female, and 0 otherwise & Binary \\
\hline 6 & TNR & CEO Tenure & Number of years the CEO had held the position & Continuous \\
\hline 7 & AGE & CEO Age & Number of age CEO & Continuous \\
\hline 8 & EDU & CEO Education & $\begin{array}{l}1 \text { if the CEO who has master/doctoral degree, and } 0 \\
\text { otherwise }\end{array}$ & Binary \\
\hline 9 & NAT & CEO Nationality & 1 if the CEO is from foreign nations, and 0 otherwise & Binary \\
\hline \multicolumn{5}{|c|}{ Control Variables } \\
\hline \multicolumn{5}{|c|}{ Corporate Governance } \\
\hline 10 & $\mathrm{BI}$ & Board Independence & Number of independent commissioners & Continuous \\
\hline 11 & BS & Board Size & Number of commissioners & Continuous \\
\hline
\end{tabular}




\section{GENERAL MANAGEMENT}

\begin{tabular}{|l|l|l|l|l|}
\hline 12 & BD & Board Diversity & $\begin{array}{l}\text { the percentage of the number of female } \\
\text { commissioners }\end{array}$ & Continuous \\
\hline 13 & BM & Board of Meeting & number of board of commissioners meetings & Continuous \\
\hline Firm Specific & \multicolumn{5}{|l|}{} \\
\hline 14 & LEV & Leverage & Total debt / total equity & Continuous \\
\hline 15 & GROWTH & Sales Growth & $\begin{array}{l}\text { sales growth obtained from the difference between } \\
\text { current and last year's sales divided by last year's } \\
\text { sales }\end{array}$ & Continuous \\
\hline 16 & CR & Current Ratio & Current assets / current liabilities & Continuous \\
\hline 17 & FS & Firm Size & the natural logarithm of total assets & Continuous \\
\hline 18 & CF & Cash Flow & Net Income + Depreciation/total assets & Continuous \\
\hline 19 & FA & Firm Age & $\begin{array}{l}\text { calculated in years since the year the firm was } \\
\text { incorporated }\end{array}$ & Continuous \\
\hline
\end{tabular}

Table 2: Variable definition

\subsubsection{Regression model and endogeneity anticipation}

To estimate the effect between CEO characteristics on firm permofance in food and beverage in Indonesia, Malaysia, and Singapore, we adopted a panel data regression analysis by combining time-series (six years) and cross-sectional (50 companies) data. The effect between CEO characteristics and firm performance was investigated through panel data regression with the following equation model:

$$
\begin{aligned}
& \mathrm{ROA}_{\mathrm{i}, \mathrm{t}}=\alpha+\beta_{1} \mathrm{GDR}_{\mathrm{i}, \mathrm{t}}+\beta_{2} \mathrm{TNR}_{\mathrm{i}, \mathrm{t}}+\beta_{3} \mathrm{AGE}_{\mathrm{i}, \mathrm{t}}+\beta_{4} \mathrm{EDU}_{\mathrm{i}, \mathrm{t}} \\
& +\beta_{5} \mathrm{NAT}_{\mathrm{i}, \mathrm{t}}+\sum \text { Controls }+\sum \text { CountryFE } \\
& +\sum \text { YearFE }+\varepsilon_{i, t} \\
& \mathrm{ROE}_{\mathrm{i}, \mathrm{t}}=\alpha+\beta_{1} \mathrm{GDR}_{\mathrm{i}, \mathrm{t}}+\beta_{2} \mathrm{TNR}_{\mathrm{i}, \mathrm{t}}+\beta_{3} \mathrm{AGE}_{\mathrm{i}, \mathrm{t}}+\beta_{4} \mathrm{EDU}_{\mathrm{i}, \mathrm{t}} \\
& +\beta_{5} \mathrm{NAT}_{\mathrm{i}, \mathrm{t}}+\sum \text { Controls }+\sum \text { CountryFE } \\
& +\sum \text { YearFE }+\varepsilon_{i, t} \\
& \mathrm{ROS}_{\mathrm{i}, \mathrm{t}}=\alpha+\beta_{1} \mathrm{GDR}_{\mathrm{i}, \mathrm{t}}+\beta_{2} \mathrm{TNR}_{\mathrm{i}, \mathrm{t}}+\beta_{3} \mathrm{AGE}_{\mathrm{i}, \mathrm{t}}+\beta_{4} \mathrm{EDU}_{\mathrm{i}, \mathrm{t}} \\
& +\beta_{5} \mathrm{NAT}_{\mathrm{i}, \mathrm{t}}+\sum \text { Controls }+\sum \text { CountryFE } \\
& +\sum \text { YearFE }+\varepsilon_{i, t} \\
& \text { Tobin's } Q_{i, t}=\alpha+\beta_{1} G_{D R} R_{i, t}+\beta_{2} \text { TNR }_{i, t}+\beta_{3} A_{G E} i, t+\beta_{4} E_{i, t} \\
& +\beta_{5} \mathrm{NAT}_{\mathrm{i}, \mathrm{t}}+\sum \text { Controls }+\sum \text { CountryFE } \\
& +\sum \text { YearFE }+\varepsilon_{\mathrm{i}, \mathrm{t}}
\end{aligned}
$$

Where: KPit are continuous variables; The dependent variable is the firm's performance as measured by four models: ROAit is the ratio of net income divided by total assets; ROEit is the ratio of net income divided by total shareholder equity; ROSit is the ratio of net income divided by total sales; Tobin's Qit is market value share + debt divided by total assets. The subscript i for the firm (i) and subscript $t$ indicate period (t). As previously described in the variable definition, GDR, TNR, AGE, EDU, and NAT replace the main independent variables of CEO characteristics. The control variables sigma consisted of $\mathrm{BI}, \mathrm{BS}$, BD, BM, LEV, GROWTH, CR, FS, CF, and FA.

We use country fixed-effect (FE) to produce samples from various countries. The author believes that each country has different characteristics, which can raise heterogeneity between samples. To overcome this problem, the authors use country FE to hope that specific heterogeneity within a country can be minimized. In addition, the authors also use the year FE in the study to capture the effect of aggregate time-series trends and parameter changes over time. Technically, the year fixed-effect (FE) can also identify any variations in the dependent variable that occur over time and are considered independent of the remaining explanatory variables in the model. We are also aware that other potential endogenous problems may arise, as there are serial correlations within and between our units of analysis (observation), and they are related to one another. Therefore, to solve this problem, we use clustered standard error technique to produce more robust and more minor standard errors to increase the efficiency and precision of our estimates.

\section{Results and discussion}

\subsection{Descriptive statistics}

We begin discussing our findings by first presenting the descriptive statistics of our variables of interest. As a result, we provide the information based on the mean value, standard deviation, minimum, percentiles 25th, 50th, 75th, and the maximum values of each variable. Table 3 presents the essential information about descriptive statistics analysis.

Summary of descriptive statistics of the variables used. We report that the four measures of firm performance show different mean scores. The average ROA was 0.054 , the ROE average was 0.084 , and the ROS mean value was 0.025 , while Tobin's $Q$ average was 1.629. The independent variable also shows interesting results. The first proxy for female CEOs (GDR) shows that of the 50 food and beverage companies in Indonesia, Malaysia, and Singapore, only 7 percent $(0.070)$ of women are CEOs. The proxy for CEO tenure (TNR) shows that the average CEO has served in the firm for 10.98 years (10.983).

Meanwhile, at the age of CEO (AGE), the average age who served as CEO was 54.69 years (54.687). On the other dummy variable proxies, CEO education (EDU), shows that 68.7 percent of those who served as CEOs had a master / doctoral degrees. The final proxy for CEO nationality (NAT) shows that 33.3 percent of CEOs come from foreign countries. 


\section{GENERAL MANAGEMENT}

\begin{tabular}{|l|l|l|l|l|l|l|l|l|l|}
\hline No & Variables & Obs. & Mean & SD & Min & p.25th & p.50th & p.75th & Max \\
\hline 1 & ROA & 300 & 0.054 & 0.159 & -1.469 & 0.014 & 0.048 & 0.103 & 0.530 \\
\hline 2 & ROE & 300 & 0.084 & 0.805 & -13.10 & 0.030 & 0.089 & 0.163 & 1.420 \\
\hline 3 & ROS & 300 & 0.025 & 0.268 & -3.082 & 0.011 & 0.047 & 0.098 & 0.739 \\
\hline 4 & TOBIN'S Q & 300 & 1.629 & 4.537 & -1.174 & 0.139 & 0.430 & 0.867 & 37.197 \\
\hline 5 & GDR & 300 & 0.070 & 0.256 & 0.000 & 0.000 & 0.000 & 0.000 & 1.000 \\
\hline 6 & TNR & 300 & 10.983 & 9.146 & 1.000 & 4.000 & 8.000 & 16.000 & 46.000 \\
\hline 7 & AGE & 300 & 54.687 & 10.065 & 35.000 & 47.000 & 54.000 & 63.000 & 77.000 \\
\hline 8 & EDU & 300 & 0.687 & 0.465 & 0.000 & 0.000 & 1.000 & 1.000 & 1.000 \\
\hline 9 & NAT & 300 & 0.333 & 0.472 & 0.000 & 1.000 & 0.000 & 1.000 & 1.000 \\
\hline 10 & BI & 300 & 3.007 & 1.617 & 1.000 & 2.000 & 3.000 & 3.500 & 8.000 \\
\hline 11 & BS & 300 & 6.140 & 2.524 & 2.000 & 4.000 & 6.000 & 8.000 & 12.000 \\
\hline 12 & BD & 300 & 0.081 & 0.112 & 0.000 & 0.000 & 0.000 & 0.167 & 0.429 \\
\hline 13 & BM & 300 & 5.390 & 2.423 & 0.000 & 4.000 & 5.000 & 6.000 & 16.000 \\
\hline 14 & LEV & 300 & 0.506 & 0.763 & 0.006 & 0.238 & 0.403 & 0.572 & 9.366 \\
\hline 15 & GROWTH & 300 & 0.173 & 1.663 & -0.999 & -0.035 & 0.049 & 0.132 & 28.024 \\
\hline 16 & GR & 300 & 2.769 & 5.233 & 0.057 & 1.204 & 1.644 & 2.924 & 69.684 \\
\hline 17 & FS & 300 & 15.270 & 3.482 & 1.022 & 13.346 & 14.733 & 18.199 & 28.203 \\
\hline 18 & GF & 300 & 0.151 & 0.410 & -1.370 & 0.040 & 0.101 & 0.192 & 5.312 \\
\hline 19 & FA & 300 & 43.927 & 30.305 & 1.000 & 22.000 & 37.500 & 54.000 & 135.000 \\
\hline
\end{tabular}

Table 3: Descriptive statistics

\subsection{Correlation analysis}

Table 4 presents the correlation analysis output. In the dependent variable, ROA and ROS are highly correlated $(r=$ $0.85)$ positively and significantly $(p<0.01)$. Since the two dependent variables are tested empirically and in separate models, there is no concern about the high correlation of the dependent variable. Furthermore, it was noted that there was no evidence that there was multicollinearity because there was no correlation linking the two independent variables as significant above $(r=0.50)$. Among the independent variables, CEO gender correlates to ROS and Tobin's $Q$ at a 1 percent level of significance, CEO tenure, CEO age, and CEO education are only correlated in Tobin's $Q$ at the 1 percent and 5 percent significance levels. In contrast, CEO nationality correlates with ROA, ROE, and ROS at the 5 percent and 10 percent significance levels.

\subsection{Main analysis}

The results of the hypotheses testing are available in Table 5 , which details the primary analysis. In hypothesis one, it assumed that CEO gender positively affects firm performance. Hypothesis two assumes that CEO tenure positively affects firm performance; hypothesis three assumes that CEO age positively affects firm performance. Hypothesis four assumes that CEO education positively affects firm performance, and hypothesis five assumes that CEO nationality positively affects firm performance.
This regression adopts a fixed-effect model (FEM)with a different scheme, namely country FE and year FE. We realize that each country certainly has different characteristics, which can lead to heterogeneity among the samples. Therefore, in anticipating this, we use country FE in our study. In addition, we also use the year FE to take the effect of aggregate time-series trends and changes in parameters over time. In dealing with autocorrelation and heterogeneity between samples, we also use clustered standard error techniques to obtain efficient results.

Based on the test result in Table 5, which details the main analyzes. In model D, CEO gender has a significant positive effect on Tobin's $Q$, with a coefficient value $(\beta=0.4915)$ and significantly $(p<0.01)$. In contrast, in model $A, C E O$ gender has a positive and insignificant effect on ROA with a coefficient $(\beta=$ 0.0021 ), in model $B$, CEO gender has a negative and insignificant effect on ROE with a coefficient $(\beta=-0.1906)$, and in model $C$ CEO gender has a negative and insignificant effect on $\operatorname{ROS}(\beta=-0.0390)$. 


\section{GENERAL MANAGEMENT}

\begin{tabular}{|c|c|c|c|c|c|c|c|c|c|c|c|c|c|c|c|}
\hline Variable & GDR & TNR & AGE & EDU & NAT & $\mathrm{BI}$ & BS & BD & BM & LEV & GROWTH & CR & FS & CF & FA \\
\hline GDR & 1.00 & & & & & & & & & & & & & & \\
\hline TNR & -0.09 & 1.00 & & & & & & & & & & & & & \\
\hline AGE & $-0.21^{* \star *}$ & $0.46^{* \star *}$ & 1.00 & & & & & & & & & & & & \\
\hline EDU & $0.13^{*}$ & $0.17^{* *}$ & $0.15^{*}$ & 1.00 & & & & & & & & & & & \\
\hline NAT & 0.03 & $-0.31^{* * *}$ & -0.07 & $-0.18^{* *}$ & 1.00 & & & & & & & & & & \\
\hline $\mathrm{BI}$ & $-0.18^{\star *}$ & $-0.30^{\star \star \star}$ & $-0.15^{* *}$ & $-0.22^{* \star \star}$ & $0.29^{\star \star \star}$ & 1.00 & & & & & & & & & \\
\hline BS & $-0.29^{\star \star *}$ & $-0.23^{* * *}$ & -0.01 & $-0.23^{\star \star \star}$ & $0.14^{*}$ & $0.71^{* \star \star}$ & 1.00 & & & & & & & & \\
\hline$B D$ & $-0.20^{* * *}$ & $-0.19^{* *}$ & -0.09 & $-0.12^{*}$ & 0.09 & $0.22^{\star \star \star}$ & $0.26^{* * *}$ & 1.00 & & & & & & & \\
\hline $\mathrm{BM}$ & 0.03 & 0.04 & $0.19^{\star *}$ & $0.17^{\star *}$ & $-0.12^{*}$ & $-0.17^{* *}$ & -0.03 & -0.08 & 1.00 & & & & & & \\
\hline LEV & -0.06 & $0.15^{*}$ & 0.00 & $0.16^{* *}$ & -0.07 & $-0.13^{*}$ & $-0.15^{\star \star}$ & 0.08 & 0.06 & 1.00 & & & & & \\
\hline GROWTH & -0.00 & -0.04 & -0.07 & 0.06 & -0.07 & -0.06 & -0.05 & 0.05 & -0.03 & 0.05 & 1.00 & & & & \\
\hline CR & 0.02 & $-0.11^{*}$ & 0.05 & $-0.20^{* * *}$ & -0.00 & 0.03 & 0.09 & 0.08 & -0.02 & $-0.14^{*}$ & -0.01 & 1.00 & & & \\
\hline FS & -0.08 & -0.04 & -0.08 & 0.03 & -0.08 & $0.21^{* \star \star}$ & $0.21^{* \star \star}$ & -0.04 & $-0.23^{\star \star \star}$ & $-0.15^{\star *}$ & 0.07 & 0.09 & 1.00 & & \\
\hline CF & -0.06 & 0.11 & 0.06 & 0.11 & -0.03 & -0.11 & -0.04 & 0.08 & $0.14^{*}$ & $0.44^{* * *}$ & 0.01 & -0.04 & $-0.24^{\star \star \star}$ & 1.00 & \\
\hline Observations & 300 & & & & & & & & & & & & & & \\
\hline
\end{tabular}

Table 4: Matrix correlations

${ }^{* * *} p<0.01,{ }^{* *} p<0.05,{ }^{*} p<0.1$ indicate statistical significance at the 1 percent, 5 percent and 10 percent level respectively (two-tailed). 


\section{GENERAL MANAGEMENT}

The effect of CEO tenure on firm performance. Based on the result in Table 5, in model $\mathrm{A}$, model $\mathrm{B}$, and model $\mathrm{C}, \mathrm{CEO}$ tenure (TNR) has a negative and insignificant effect on ROA, ROE, and ROS with a coefficient $(\beta=-0.0007,-0.0115,-0.0016)$. While in model $D, C E O$ tenure (TNR) has a positive and insignificant effect on Tobin's $Q$ with a coefficient $(\beta=0.0016)$. Then, the effects of CEO age (AGE) on firm performance are described in Table 5. The result, in model $A, C E O$ age (AGE) has a negative and insignificant effect on ROA with a coefficient $(\beta=-0.0006)$, in model $B$, CEO age (AGE) has a positive and insignificant effect on ROE with a coefficient $(\beta=0.0072)$, in model C CEO age (AGE) has a negative and insignificant effect on ROS with a coefficient $(\beta=-0.0003$ ) and in model D CEO age (AGE) has a negative and insignificant effect on Tobin's $Q(\beta=-0.0094)$. The effect of CEO education on firm performance, in model $A$ and model $C$ CEO education (EDU), has a positive and insignificant effect on ROA and ROS with a coefficient $(\beta=$ $0.0509)$ and $(\beta=0.1213)$, while in model $B$ and model $D$ has negative and insignificant effect on ROE and Tobin's $Q$ with a coefficient $(\beta=-0.2558)$ and $(\beta=-0.5256)$.

\begin{tabular}{|c|c|c|c|c|}
\hline \multirow{2}{*}{ VARIABLES } & ROA & ROE & ROS & TOBIN'S Q \\
\hline & Model A & Model B & Model C & Model D \\
\hline \multirow[t]{2}{*}{ GDR } & 0.0021 & -0.1906 & -0.0390 & $0.4915^{\star \star *}$ \\
\hline & $(0.925)$ & $(0.141)$ & $(0.438)$ & $(0.002)$ \\
\hline \multirow[t]{2}{*}{ TNR } & -0.0007 & -0.0115 & -0.0016 & 0.0016 \\
\hline & $(0.557)$ & $(0.331)$ & $(0.515)$ & $(0.870)$ \\
\hline \multirow[t]{2}{*}{ AGE } & -0.0006 & 0.0072 & -0.0003 & -0.0094 \\
\hline & $(0.685)$ & $(0.315)$ & $(0.920)$ & $(0.462)$ \\
\hline \multirow[t]{2}{*}{ EDU } & 0.0509 & -0.2558 & 0.1213 & -0.5256 \\
\hline & \begin{tabular}{|l}
$(0.165)$ \\
\end{tabular} & $(0.248)$ & $(0.132)$ & $(0.163)$ \\
\hline \multirow[t]{2}{*}{ NAT } & $0.0322^{* *}$ & 0.1371 & -0.0015 & $2.4043^{* * *}$ \\
\hline & $(0.013)$ & $(0.379)$ & $(0.934)$ & $(0.000)$ \\
\hline \multirow[t]{2}{*}{$\mathrm{BI}$} & 0.0305 & -0.0186 & 0.0655 & 0.3485 \\
\hline & $(0.379)$ & $(0.746)$ & $(0.386)$ & $(0.492)$ \\
\hline \multirow[t]{2}{*}{ BS } & -0.0141 & -0.1793 & 0.0044 & -0.3389 \\
\hline & $(0.220)$ & $(0.153)$ & $(0.769)$ & $(0.125)$ \\
\hline \multirow[t]{2}{*}{$\mathrm{BD}$} & -0.0643 & 0.3833 & -0.0832 & 1.2365 \\
\hline & \begin{tabular}{|l}
$(0.424)$ \\
\end{tabular} & $(0.477)$ & $(0.577)$ & $(0.120)$ \\
\hline \multirow[t]{2}{*}{$\mathrm{BM}$} & $0.0055^{\star * *}$ & 0.0135 & 0.0108 & -0.0475 \\
\hline & $(0.006)$ & $(0.258)$ & $(0.105)$ & $(0.334)$ \\
\hline \multirow[t]{2}{*}{ LEV } & \begin{tabular}{|l|}
-0.0455 \\
\end{tabular} & 0.0668 & -0.0787 & -0.2312 \\
\hline & $(0.274)$ & $(0.375)$ & $(0.355)$ & $(0.448)$ \\
\hline \multirow{2}{*}{ GROWTH } & 0.0027 & 0.0080 & 0.0095 & -0.0217 \\
\hline & $(0.599)$ & $(0.537)$ & $(0.467)$ & $(0.623)$ \\
\hline \multirow[t]{2}{*}{ CR } & 0.0012 & $0.0062^{* *}$ & 0.0009 & 0.0007 \\
\hline & $(0.116)$ & $(0.021)$ & $(0.456)$ & $(0.953)$ \\
\hline \multirow[t]{2}{*}{ FS } & 0.0027 & -0.0054 & 0.0114 & 0.1588 \\
\hline & $(0.586)$ & $(0.696)$ & $(0.280)$ & $(0.171)$ \\
\hline \multirow[t]{2}{*}{$\mathrm{CF}$} & 0.1402 & 0.0113 & 0.2329 & 0.5509 \\
\hline & $(0.102)$ & $(0.895)$ & $(0.188)$ & $(0.402)$ \\
\hline \multirow[t]{2}{*}{ FA } & $0.1823^{* * *}$ & 0.0623 & $0.3120^{* * *}$ & $0.7797^{* *}$ \\
\hline & \begin{tabular}{|l|}
$(0.000)$ \\
\end{tabular} & $(0.747)$ & $(0.006)$ & $(0.030)$ \\
\hline \multirow[t]{2}{*}{ Constant } & $-7.5515^{\star \star \star}$ & -1.4784 & $-13.3655^{\text {** }}$ & $-31.7827^{* *}$ \\
\hline & $(0.001)$ & $(0.861)$ & $(0.008)$ & $(0.046)$ \\
\hline Observations & 300 & 300 & 300 & 300 \\
\hline R-squared & 0.2277 & 0.0554 & 0.1784 & 0.1198 \\
\hline Number of companies & \begin{tabular}{|l|l|}
50 \\
\end{tabular} & 50 & 50 & 50 \\
\hline Clustered SE & YES & YES & YES & YES \\
\hline Year FE & YES & YES & YES & YES \\
\hline Country FE & YES & YES & YES & YES \\
\hline
\end{tabular}

Finally, the effect of CEO nationality and firm performance is described in Table 5 with the results; in the model, A CEO nationality (NAT) has a positive and significant effect on ROA with a coefficient $(\beta=0.0322)$ and significantly $(p<0.05)$ and in model D CEO nationality (NAT) has a positive and significant effect on Tobin's $Q$ with a coefficient $(\beta=2.4043)$ and significantly $(p<0.01)$. While, in model $B$, CEO nationality (NAT) has a positive and insignificant effect on ROE with a coefficient $(\beta=0.1371)$, in model $C$, CEO nationality (NAT) has a negative and insignificant effect on ROS with a coefficient $(\beta=-.0015)$.

We tested the results by looking at the independent variable.
It concluded that CEO gender as proxied by the female CEO dummy shows a positive and significant effect with firm performance measured with Tobin's $Q$ at the 1 percent significance level. However, it does not show a significant effect to other proxies of firm performance (ROA, ROE, and ROS), so hypothesis one $(\mathrm{H} 1)$ are rejected. CEO tenure, CEO age, and CEO education do not have a significant effect to firm performance, so hypothesis two $(\mathrm{H} 2)$, hypothesis three $(\mathrm{H} 3)$, and hypothesis four $(\mathrm{H} 4)$ are rejected. Meanwhile, CEO nationality has a significant effect with firm performance as measured by ROA and Tobin's $Q$ at the 1 percent and 5 percent 
significance levels, so hypothesis five $(\mathrm{H} 5)$ is accepted. The results are shown in Table 5 .

\subsection{Discussion}

Our study is expected to fill in the research gap in the deliberation by previous studies relating to CEOs gender, CEO tenure, CEO age, CEO education, and CEO nationality and their effect on firm performance. To address this gap, we propose five hypotheses questioning the effect of CEO gender on firm performance, CEO tenure on firm performance, CEO age on firm performance, CEO education on firm performance, and CEO nationality on firm performance. The results give mixed evidence. This study contributes to the burgeoning literature on CEO characteristics by providing empirical evidence on the effect of female CEOs on firm performance, CEO tenure on firm performance, CEO age on firm performance, CEO education on firm performance, and CEO nationalism on firm performance. We add to the limited research on upper echelon theory that addresses such an issue in the food and beverages industry in Indonesia, Malaysia, and Singapore.

Mainly, we used five CEO characteristics and further tested them on four measures of firm performance (ROA, ROE, ROS, and Tobin's Q). We observed mixed results. Based on the regression results, CEO gender, which is proxied by the female CEO dummy, does not significantly affect firm performance (ROA, ROE, and ROS). In contrast, female CEO is positively and significantly affect Tobin's $Q$. The number of women who can occupy positions as CEOs is minimal in this sample, which means that female CEO will not affect firm performance. These results also indicate that female and male CEO can provide better firm performance, but both can also reduce firm performance. Based on these results, it can be stated that the first hypothesis $(\mathrm{H} 1)$, which states that CEO gender has a positive and significant effect on firm firm performance, is rejected. These results do not support the research conducted by Khan \& Vieito (2013), Mahbubi (2016), Rahman et al. (2017), which states that CEO gender has a positive and significant effect on firm performance. However, these results are in line with the research conducted by Baloyi \& Ngwakwe (2017) and Fujianti (2018).

CEO tenure does not significantly affect firm performance (ROA, ROE, ROS, and Tobin's Q). It is because CEOs with a long tenure may be in their comfort zone. Market situations and conditions are unstable, and changes are inevitable, so companies need fresh thinking to create a competitive firm, and this may be the reason for not having a CEO with a long tenure (Kusumasari, 2018). Based on these results, it can be stated that the second hypothesis $(\mathrm{H} 2)$, which states that CEO tenure has a positive and significant effect on firm performance, is rejected. These results do not support the research conducted by Diks (2016), Emestine \& Setyaningrum (2019), Hidayati (2017), Sudana \& Aristina (2017), which state that having a long tenure CEO will improve firm performance. This result is in line with research conducted by Arbogast \& Mirabella (2014) and Kusumasari (2018), which state that CEO tenure does not affect firm performance.

Furthermore, CEO age does not significantly affect firm performance (ROA, ROE, ROS, and Tobin's Q). It explains that either a firm led by a young or old CEO will positively impact firm performance, but both can reduce the firm's performance. It could be because every age has different competitiveness from one another. Old age is with their experience and insight, while young age is careful in taking risks and understanding the situation and situation of the world market (Kusumasari, 2018). Based on these results, it can be stated that the third hypothesis $(\mathrm{H} 3)$, which states that CEO age has a positive and significant effect on firm performance, is rejected. This result is not in line with the research conducted by Emestine \& Setyaningrum
(2019) and Xie (2015), which state that the older the CEO, the more extensive work experience and insight will later improve firm performance. This result also does not support the upper echelon theory, which says that age is one of the dimensions of CEO characteristics that can affect firm performance (Hambrick \& Mason, 1984).

Then, CEO education, proxied by the dummy CEO with a master's degree / Doctoral degree, does not significantly affect firm performance (ROA, ROE, ROS, and Tobin's Q). Different levels of the CEO's educational background will affect the knowledge, insight, and expertise in reading the situation or state of the firm. Based on these results, it can be stated that the fourth hypothesis $(\mathrm{H} 4)$, which states that CEO education has a positive and significant effect on firm performance, is rejected and in line with the research conducted by Ayaba (2012), Gottesman \& Morey (2006), Jannah (2015), Putri \& Herawaty (2019). The CEO with a master's degree / Doctoral degree has broad insight in intellectual matters but has minimal experience in managing firm situations and implementing decisions and actions to improve firm performance.

Finally, CEO nationality, which is proxied by a foreign CEO dummy, does not significantly affect ROE and ROS. However, CEO nationality is significantly and positively affect Tobin's $Q$ and ROA. The existence of a foreign CEO will have a good impact on the board of managers. With a foreign CEO's background, it will be a new added value or new insight for managers on how to manage a firm and a separate success factor for the firm. Based on these results, it can be stated that the fifth hypothesis $(\mathrm{H} 5)$, which states that CEO nationality has a positive and significant effect on firm performance, is accepted. These results support the research conducted by Ararat et al. (2010), Putri et al. (2021), Sanda et al. (2010), which states that companies managed by foreign CEOs can offer valuable ideas, knowledge, and expertise so that they can improve firm performance.

Particularly, this research has several implications. For companies and shareholders, they shoud appoint a woman as CEO based on her expertise and experience, not on the basis of family relationships. Companies and shareholders should also consider appointing a CEO who has experience in the same industry, namely food and beverage. Companies and shareholders also need to consider appointing a CEO who has the same educational background with the food and beverage sector. The firm and shareholders also continue to consider appointing foreign CEOs who have international experience in the food and beverage sector because they can improve firm performance (ROA and Tobin's $Q$ ).

\subsection{Robustness Check}

The regressions were used to check the robustness of the main results, and the outputs are presented in Table 6 . We divide samples into sub-samples that are Indonesia, Malaysia, and Singapore. Table 6 shows that GDR (female CEO) does not significantly affect firm performance, except for ROE in Indonesia and Tobin's $Q$ in Malaysia and Singapore. Second, TNR (CEO tenure) does not significantly affect firm performance, except for ROA in Malaysia and Singapore, ROS in Malaysia, and Tobin's Q in Singapore. Third, AGE (CEO age) does not significantly affect firm performance, except for ROA in Malaysia and Singapore. Fourth, EDU (CEO education) does not significantly affect firm performance (all measures) in Indonesia, Malaysia, and Singapore. Fifth, NAT (CEO nationality) has a mixed influence, namely a significant influence on ROA and ROE in Indonesia and a significant influence on Tobin's Q in Indonesia, Malaysia, and Singapore. However, CEO nationality has no significant effect on ROA and ROE in Malaysia and Singapore and on ROS in Indonesia, Malaysia, and Singapore. 


\section{GENERAL MANAGEMENT}

\begin{tabular}{|c|c|c|c|c|c|c|c|c|c|c|c|c|}
\hline \multirow[t]{2}{*}{ Variables } & \multicolumn{2}{|r|}{ ROA } & \multicolumn{3}{|r|}{ ROE } & \multicolumn{3}{|r|}{ ROS } & & \multicolumn{2}{|r|}{ Tobin's Q } & \multirow[b]{2}{*}{ Singapura } \\
\hline & Indonesia & Malaysia & Singapura & Indonesia & Malaysia & Singapura & Indonesia & Malaysia & Singapura & Indonesia & Malaysia & \\
\hline \multirow[t]{2}{*}{ GDR } & 0.0052 & 0.0076 & -0.0281 & $-0.0847^{* *}$ & 0.4082 & 0.0382 & 0.0045 & -0.1050 & 0.0330 & 0.3732 & 2.2869** & $-0.4991^{* *}$ \\
\hline & $(0.688)$ & $(0.674)$ & $(0.158)$ & $(0.019)$ & $(0.551)$ & $(0.664)$ & $(0.937)$ & $(0.321)$ & $(0.563)$ & $(0.691)$ & $(0.029)$ & $(0.016)$ \\
\hline \multirow[t]{2}{*}{\begin{tabular}{|l|l|} 
TNR \\
\end{tabular}} & -0.0000 & $-0.0083^{*}$ & $0.0027^{* *}$ & -0.0003 & -0.0137 & 0.0009 & 0.0001 & $-0.0366^{*}$ & -0.0000 & -0.0065 & -0.0790 & $0.0247^{*}$ \\
\hline & $(0.917)$ & $(0.062)$ & $(0.046)$ & $(0.766)$ & $(0.919)$ & $(0.882)$ & $(0.921)$ & $(0.054)$ & $(0.997)$ & $(0.807)$ & $(0.711)$ & $(0.053)$ \\
\hline \multirow[t]{2}{*}{ AGE } & -0.0012 & $-0.0024^{* *}$ & $-0.0028^{* *}$ & -0.0001 & -0.0451 & -0.0007 & -0.0038 & -0.0076 & -0.0010 & -0.0192 & -0.0319 & -0.0128 \\
\hline & $(0.358)$ & $(0.046)$ & $(0.013)$ & $(0.989)$ & $(0.311)$ & $(0.886)$ & $(0.203)$ & $(0.179)$ & $(0.726)$ & $(0.760)$ & $(0.614)$ & $(0.260)$ \\
\hline \multirow[t]{2}{*}{ EDU } & 0.0275 & 0.0625 & -0.0113 & -0.0043 & 0.8266 & -0.0187 & 0.0331 & 0.2018 & -0.0100 & -0.3806 & 0.7737 & -0.0976 \\
\hline & $(0.143)$ & $(0.141)$ & $(0.226)$ & $(0.893)$ & $(0.491)$ & $(0.375)$ & $(0.305)$ & $(0.297)$ & $(0.516)$ & $(0.608)$ & $(0.705)$ & $(0.204)$ \\
\hline \multirow[t]{2}{*}{ NAT } & $0.0380^{*}$ & 0.0310 & -0.0128 & $0.0770^{*}$ & 0.1353 & 0.0145 & 0.0212 & 0.1279 & -0.0283 & $1.8292^{* * *}$ & $3.4591^{* * *}$ & $-0.3965^{\star *}$ \\
\hline & $(0.070)$ & $(0.140)$ & $(0.161)$ & $(0.099)$ & $(0.829)$ & (0754) & $(0.766)$ & $(0.229)$ & $(0.430)$ & $(0.009)$ & $(0.004)$ & $(0.028)$ \\
\hline \multirow[t]{2}{*}{$\mathrm{BI}$} & -0.0362 & 0.0016 & $-0.0186^{\star \star \star}$ & -0.0973 & -0.0227 & 0.0062 & -0.0441 & 0.0102 & $-0.0383^{\star * *}$ & -0.6168 & 0.7555 & -0.0851 \\
\hline & $(0.392)$ & $(0.419)$ & $(0.000)$ & $(0.320)$ & $(0.800)$ & $(0.689)$ & $(0.128)$ & $(0.457)$ & $(0.000)$ & $(0.593)$ & $(0.310)$ & $(0.246)$ \\
\hline \multirow[t]{2}{*}{$B S$} & -0.0211 & -0.0041 & 0.0035 & 0.0349 & 0.2197 & -0.0014 & 0.0278 & -0.0261 & $0.0240^{* \star *}$ & -0.2635 & -0.1432 & $-0.0667^{* * *}$ \\
\hline & $(0.385)$ & $(0.266)$ & $(0.113)$ & $(0.295)$ & $(0.448)$ & $(0.878)$ & $(0.541)$ & $(0.375)$ & $(0.002)$ & $(0.363)$ & $(0.626)$ & $(0.008)$ \\
\hline \multirow[t]{2}{*}{ BD } & 0.0005 & -0.0168 & -0.0088 & 0.0074 & 0.3887 & -0.1088 & -0.0854 & 0.0417 & -0.0236 & 0.7489 & 0.3703 & 0.3692 \\
\hline & $(0.993)$ & $(0.544)$ & $(0.749)$ & $(0.943)$ & $(0.605)$ & $(0.455)$ & $(0.503)$ & $(0.792)$ & $(0.699)$ & $(0.761)$ & $(0.876)$ & $(0.410)$ \\
\hline \multirow[t]{2}{*}{ BM } & $0.0042^{* *}$ & -0.0008 & 0.0013 & $0.0067^{*}$ & 0.0210 & $0.0226^{* * *}$ & 0.0103 & -0.0234 & -0.0046 & 0.0174 & -0.4337 & 0.0392 \\
\hline & $(0.019)$ & $(0.733)$ & $(0.583)$ & $(0.066)$ & $(0.823)$ & $(0.009)$ & $(0.171)$ & $(0.416)$ & $(0.566)$ & $(0.779)$ & $(0.159)$ & $(0.159)$ \\
\hline \multirow[t]{2}{*}{ LEV } & -0.0019 & $-0.0247^{* * *}$ & -0.0100 & 0.0031 & $2.6584^{* *}$ & 0.0342 & 0.0014 & $-0.2342^{* * *}$ & -0.0350 & -0.3058 & 1.1335 & 0.1073 \\
\hline & $(0.706)$ & $(0.010)$ & $(0.491)$ & $(0.756)$ & $(0.022)$ & $(0.783)$ & $(0810)$ & $(0.000)$ & $(0.507)$ & $(0.525)$ & $(0.159)$ & $(0.719)$ \\
\hline \multirow[t]{2}{*}{ GROWTH } & -0.0006 & -0.0000 & 0.0040 & -0.0271 & -0.0164 & -0.0082 & $0.0870^{* * *}$ & 0.0009 & -0.0347 & $-1.5605^{*}$ & 0.0051 & 0.0005 \\
\hline & $(0.967)$ & $(0.808)$ & $(0.736)$ & $(0.357)$ & $(0.373)$ & $(0.767)$ & $(0.000)$ & $(0.682)$ & $(0.355)$ & $(0.067)$ & $(0.568)$ & $(0.994)$ \\
\hline \multirow[t]{2}{*}{ CR } & 0.0028 & $0.0010^{\star \star *}$ & 0.0009 & 0.0063 & -0.0022 & 0.0015 & 0.0062 & 0.0022 & 0.0058 & -0.1224 & 0.0033 & $-0.0295^{\star}$ \\
\hline & $(0.257)$ & $(0.0000)$ & $(0.455)$ & $(0.425)$ & $(0.908)$ & $(0.819)$ & $(0.553)$ & $(0.107)$ & $(0.116)$ & $(0.611)$ & $(0.825)$ & $(0.052)$ \\
\hline \multirow[t]{2}{*}{ FS } & -0.0013 & 0.0028 & $0.0110^{* * *}$ & $-0.0043^{*}$ & -0.0473 & 0.0065 & 0.0044 & 0.0188 & $0.0145^{\star \star \star}$ & 0.2387 & -0.0042 & $0.1609^{\star \star \star}$ \\
\hline & $(0.171)$ & $(0.363)$ & $(0.000)$ & $(0.061)$ & $(0.689)$ & $(0.447)$ & $(0.343)$ & $(0.326)$ & $(0.010)$ & $(0.288)$ & $(0.963)$ & $(0.001)$ \\
\hline \multirow[t]{2}{*}{ CF } & $0.0214^{\star \star \star}$ & $1.0375^{\star \star \star}$ & $0.9418^{* \star *}$ & $0.0361^{*}$ & $2.3756^{*}$ & $1.5619^{\star \star \star}$ & 0.0060 & $1.9098^{\star * *}$ & $1.1122^{* \star \star}$ & 1.0044 & -0.3088 & 0.0219 \\
\hline & $(0.006)$ & $(0.000)$ & $(0.000)$ & $(0.095)$ & $(0.065)$ & $(0.000)$ & $(0.550)$ & $(0.000)$ & $(0.000)$ & $(0.297)$ & $(0.535)$ & $(0.952)$ \\
\hline \multirow[t]{2}{*}{ FA } & -0.0036 & $0.0102^{*}$ & $0.0004^{*}$ & -0.0067 & 0.0042 & -0.0002 & 0.0116 & $0.0494^{*}$ & 0.0002 & -0.2516 & 0.0663 & 0.0033 \\
\hline & $(0.392)$ & $(0.088)$ & $(0.067)$ & $(0.578)$ & $(0.981)$ & $(0.847)$ & $(0.327)$ & $(0.061)$ & $(0.624)$ & $(0.248)$ & $(0.821)$ & $(0.110)$ \\
\hline \multirow[t]{2}{*}{ Constant } & 0.3988 & $-0.2892^{* \star}$ & 0.0030 & 0.4579 & -0.0543 & -0.2444 & -0.4577 & $-1.4701^{* *}$ & -0.1726 & $14.4730^{* *}$ & -0.8299 & -0.6102 \\
\hline & $(0.106)$ & $(0.046)$ & $(0.940)$ & $(0.155)$ & $(0.993)$ & $(0.254)$ & $(0.386)$ & $(0.030)$ & $(0.186)$ & $(0.022)$ & $(0.921)$ & $(0.120)$ \\
\hline Observations & 96 & 114 & 90 & 96 & 114 & 90 & 96 & 114 & 90 & 96 & 114 & 90 \\
\hline R-squared & 0.2781 & 0.9981 & 0.9876 & 0.2387 & 0.2304 & 0.8640 & 0.3304 & 0.9308 & 0.7605 & 0.2654 & 0.3972 & 0.1619 \\
\hline Clustered SE & YES & YES & YES & YES & YES & YES & YES & YES & YES & YES & YES & YES \\
\hline Year FE & YES & YES & YES & YES & YES & YES & YES & YES & YES & YES & YES & YES \\
\hline
\end{tabular}

Table 6: Robustness tests

${ }^{* *} p<0.01,{ }^{* *} p<0.05,{ }^{*} p<0.1$ indicate statistical significance at the 1 percent, 5 percent and 10 percent level respectively (two-tailed). P-values are available in parentheses. 


\section{Conclusion}

Our study explores the effect on CEOs' characteristics on firm performance. The study is motivated by previous literature detailing that CEOs' characteristics may affect to firm performance. The findings in this study, CEO gender, show that it does not have a significant effect to firm performance (ROA, ROE, and ROS). But, CEO gender has a significant effect on firm performance measured with Tobin's $Q$. The number of women who can occupy positions as CEOs is minimal in this sample, making it possible that female CEOs will not affect firm performance. CEO tenure (TNR) does not affect firm performance. CEOs with longer tenure put them in their comfort zone, so they put less investment in innovation and firm development.

Furthermore, CEO age (AGE) does not affect firm performance. It is due to the lack of experience and expertise possessed by younger CEOs, so implementing innovative strategy decisions for firm growth is still considered lacking. Then, CEO education (EDU) does not affect firm performance. CEOs with master/doctor degrees do not have a better performance to improve firm performance than CEOs who only have a bachelor's degree. Finally, CEO nationality (NAT) has a positive and significant effect on firm performance as measured by ROA and Tobin's $Q$. It is because foreign CEOs can offer valuable ideas, knowledge, and expertise to improve firm performance and its value to the market. Robustness tests confirm that CEO education is not significantly affect firm performance (all measures), and CEO nationality is significantly affect Tobin's $Q$ in Indonesia, Malaysia, and Singapore in the main regressions.

The results of this study cannot be generalized to other sectors, such as the financial sector, property sector, and others. The following study could use the number of women on the board of management, CEO tenure in the same industry, and CEOs who graduated from top universities or not.

\section{References}

[1] Wu, S., Quan, X., \& Xu, L. (2011). CEO power, disclosure quality and the variability of firm performance. Nankai Business $\begin{array}{lll}\text { Review International, } & 2(1), & \text { 79-97. }\end{array}$ doi:10.1108/20408741111113510

[2] Hambrick, D. C., \& Mason, P. A. (1984). Upper Echelons: The Organization as a Reflection of Its Top Managers. Academy of Management Review, 9(2), 193-206. doi:10.5465/amr.1984.4277628

[3] Johnson, S. G., Schnatterly, K., \& Hill, A. D. (2012). Board Composition Beyond Independence. Journal of Management, 39(1), 232-262. doi:10.1177/0149206312463938

[4] Khan, W. A., \& Vieito, J. P. (2013). Ceo gender and firm performance. Journal of Economics and Business, 67, 55-66. doi:10.1016/j.jeconbus.2013.01.003

[5] Khan, W. A., \& Vieito, J. P. (2013). Ceo gender and firm performance. Journal of Economics and Business, 67, 55-66. doi:10.1016/j.jeconbus.2013.01.003

[6] Peni, E., \& Vähämaa, S. (2010). Female executives and earnings management. Managerial Finance, 36(7), 629-645. doi:10.1108/03074351011050343

[7] Jadiyappa, N., Jyothi, P., Sireesha, B., \& Hickman, L. E. (2019). CEO gender, firm performance and agency costs: evidence from India. Journal of Economic Studies, 46(2), 482-495. doi:10.1108/jes-08-2017-0238

[8] Baloyi, S. L., \& Ngwakwe, C. C. (2017). Chief executive officer's gender and firm performance in the JSE SRI firms. Corporate Board Role Duties and Composition, 13(1), 73-78. doi:10.22495/cbv13i1c1art1

[9] Fujianti, L. (2018). Top Management Characteristics and
Company Performance: An Empirical Analysis on Public Companies Listed in the Indonesian Stock Exchange. EUROPEAN RESEARCH STUDIES JOURNAL, XXI(Issue 2), 62-76. doi:10.35808/ersj/985

[10] Rahman, H. U., Ibrahim, M. Y., \& Che Ahmad, A. (2017). Physical Characteristics of the Chief Executive Officer and Firm Accounting and Market-Based Performance. Asian Journal of Accounting and Governance, 8, 27-37. doi:10.17576/ajag2017-08-03

[11] Suherman, S., Usman, B., Mahfirah, T. F., \& Vesta, R. (2021). Do female executives and CEO tenure matter for corporate cash holdings? Insight from a Southeast Asian country. Corporate Governance: The International Journal of Business in Society, 21(5), 939-960. doi:10.1108/cg-07-2020-0290

[12] Sudana, I. M., \& Aristina, N. P. N. (2017). CHIEF EXECUTIVE OFFICER (CEO) POWER, CEO KELUARGA, DAN NILAI IPO PREMIUM PERUSAHAAN KELUARGA DI INDONESIA. Jurnal Akuntansi, 21(2), 219. doi:10.24912/ja.v21i2.196

[13] Hidayati, N. (2017). Pengaruh masa jabatan direktur utama, direksi asing, kepemilikan manajerial, kepemilikan institusional, administrative expense ratio, dan ukuran perusahaan terhadap nilai perusahaan (Studi empiris pada perusahaan manufaktur yang terdaftar di bursa efek Indonesia. Jurnal Profita, 2(1), 115.

[14] Emestine, I. E., \& Setyaningrum, D. (2019). CEO characteristics and firm performance: Empirical studies from ASEAN countries. Proceedings Iconies 2018, Atlantic Press, 423-427.

[15] Al-Matari, E. M., Al-Swidi, A. K., Fadzil, F. H., \& Al-Matari, Y. A. (2012). The Impact of board characteristics on Firm Performance: Evidence from Nonfinancial Listed Companies in Kuwaiti Stock Exchange. International Journal of Accounting and Financial Reporting, 2(2), 310. doi:10.5296/ijafr.v2i2.2384

[16] Liu, C., \& Jiang, H. (2020). Impact of CEO characteristics on firm performance: evidence from China listed firms. Applied $\begin{array}{lll}\text { Economics } \quad \text { Letters, } & \text { 27(14), }\end{array}$ doi:10.1080/13504851.2019.1607965

[17] Saidu, S. (2019). CEO characteristics and firm performance: focus on origin, education and ownership. Journal of Global Entrepreneurship Research, 9(1). doi:10.1186/s40497-0190153-7

[18] Peni, E. (2012). CEO and Chairperson characteristics and firm performance. Journal of Management \& Governance, 18(1), 185-205. doi:10.1007/s10997-012-9224-7

[19] Setiawan, R. \& Gestanti, L. (2019). Usia CEO dan kinerja perusahaan. JUIMA: Jurnal IImiah Manajemen, 9(1), 1-5.

[20] Diks, J. (2016). The impact of CEO characteristics on firm value. Unpublished Thesis, Tilburg School of Economics \& Management, 1-31.

[21] Gottesman, A. A., \& Morey, M. R. (2006). Does a better education make for better managers? An empirical examination of CEO educational quality and firm performance. Pace University Research Paper, Unpublished, 1-43.

[22] Setiawan, R., \& Gestanti, L. (2018). CEO education, karakteristik perusahaan dan kinerja perusahaan. MAGISTRA: Jurnal IImiah Manajemen, 2(2), 101-109.

[23] Ying, C.H. \& Mei, Y.C. (2014). CEO education and firm performance: Evidence from Hong Kong. Thesis, School of Business, Hong Kong Baptist University.

[24] Ayaba, O. H. (2012). Chief executive officer's (CEO's) educational background and firm performance: An empirical study on manufacturing and IT listed firms in the Stockholm stock exchange. Thesis, Umeå School of Business and Economics-MASTER.

[25] Badru, B. oleyami, \& Raji, J. O. (2016). Companies' financial outcomes in Nigeria: Does chief executive officer nationality matter? Journal of Applied Economic Sciences, 11(4), 599-615.

[26] Ujunwa, A. (2012). Board characteristics and the financial performance of Nigerian quoted firms. Corporate Governance: The International Journal of Business in Society, 12(5), 656674. doi:10.1108/14720701211275587

[27] Kaur, R., \& Singh, B. (2018). CEOs' Characteristics and Firm 


\section{GENERAL MANAGEMENT}

Performance: A Study of Indian Firms. Indian Journal of Corporate Governance, 11(2), 185-200. doi:10.1177/0974686218806714

[28] Jensen, M. C., \& Meckling, W. H. (1976). Theory of the firm: Managerial behavior, agency costs and ownership structure. Journal of Financial Economics, 3(4), 305-360. doi:10.1016/0304-405x(76)90026-X

[29] Krafft, J., Qu, Y., Quatraro, F., \& Ravix, J.-L. (2013). Corporate governance, value and performance of firms: new empirical results on convergence from a large international database. Industrial and Corporate Change, 23(2), 361-397. doi:10.1093/icc/dtt007

[30] Mahbubi, J. (2016). Gender CEO dan keputusan keuangan perusahaan di Indonesia. Doctoral Dissertation Universitas Airlangga, Unpublished.

[31] Aryati, T. (2019). Pengaruh kinerja perusahaan terhadap corporate governance reporting dengan variabel moderating CEO Tenure. Media Ekonomi Dan Manejemen, 29(1), 30-43.

[32] Chou, Y., \& Chan, M. (2018). The impact of CEO characteristics on real earnings management: Evidence from the US banking industry. Journal of Applied Finance \& Banking, 8(2), 17-44.

[33] Serfling, M. A. (2014). CEO age and the riskiness of corporate policies. Journal of Corporate Finance, 25, 251-273. doi:10.1016/j.jcorpfin.2013.12.013

[34] Maulia, S. T., \& Januarti, I. (2014). Pengaruh usia, pengalaman, dan pendidikan dewan komisaris terhadap kualitas laporan keuangan. Diponegoro Journal of Accounting, 3(3), 1-8.

[35] Darmadi, S. (2012). Board members' education and firm performance: Evidence from a developing economy. SSRN, 138.

[36] Erlim, K. W., \& Juliana, R. (2017). Pengaruh Tingkat Edukasi dan Spesialisasi Pendidikan CEO terhadap Performa Perusahaan di Indonesia. Jurnal Manajemen Maranatha, 16(2), 177. doi:10.28932/jmm.v16i2.388
[37] Pertiwi, T. K., \& Pratama, F. M. I. (2013). PENGARUH KINERJA KEUANGAN GOOD CORPORATE GOVERNANCE TERHADAP NILAI PERUSAHAAN FOOD AND BEVERAGE. Jurnal Manajemen Dan Kewirausahaan, 14(2). doi:10.9744/jmk.14.2.116-125.

[38] Buallay, A., Hamdan, A., \& Zureigat, Q. (2017). Corporate Governance and Firm Performance: Evidence from Saudi Arabia. Australasian Accounting, Business and Finance Journal, 11(1), 78-98. doi:10.14453/aabfj.v11i1.6.

[39] Kılıç, M., \& Kuzey, C. (2016). The effect of board gender diversity on firm performance: evidence from Turkey. Gender in Management, 31(7), 434-455.

[40] Kusumasari, L. (2018). Functions, age, education, tenure of CEO, and employee commitment toward firm performance. KnE Social Sciences, 3(10), 64-73.

[41] Arbogast, G., \& Mirabella, J. (2014). Predicting firm performance as a function of CEO and economic factors. The Journal of American Academy of Business, 19(2), 96-101.

[42] Xie, J. (2015). CEO career concerns and investment efficiency: Evidence from China. Emerging Markets Review, 24, 149-159. doi:10.1016/j.ememar.2015.06.001

[43] Putri, F. F. E., \& Herawaty, V. (2019). Pengaruh karakteristik CEO, struktur modal terhadap manipulasi laba dengan ukuran perusahaan sebagai pemoderasinya. Prosiding Seminar Nasional Cendekiawan V, Buku 2: Sosial dan Humaniora, 1-7.

[44] Ararat, M., Aksu, M., \& Cetin, A. (2010). The impact of board diversity on boards' monitoring intensity and firm performance: evidence from the istanbul stock exchange. SSRN, 1-33.

[45] Putri, I.D.R., Waharini, F. M., \& Purwantini, A. H. (2021). Pengaruh gender, usia, dan kebangsaan asing terhadap kinerja keuangan perusahaan. Accounting Research Journal, 1(1), 17 30.

[46] Sanda, A. U., Mikailu, A. S., \& Garba, T. (2010). Corporate governance mechanisms and firms' financial performance in Nigeria. Afro-Asian Journal of Finance and Accounting, 2(1), 22-39. 